of testing their gases in peace time; experiments on animals are liable to be fallacious, as different species vary greatly in their susceptibility to poisons, as indeed do different individuals of the same species. Moreover, when used in large quantities over extensive areas, the effects are often quite different from those obtained in small-scale experiments on a few individuals. Some indication of these difficulties may be gathered from what has been said about mustard gas and lewisite.

It is important to emphasise that practically all these substances were known before the War and were discovered in the course of purely scientific researches conducted without anticipation of the possible uses of the results in warfare. Chlorine is, of course, one of the commonest reagents of the laboratory and works, and was first made by Scheele in 1774. Phosgene was discovered by Davy in 1812. Benzyl bromide, chloropicrin and ' $\mathrm{DA}$ ' can be obtained from the dealers in chemicals, and 'DC' can be made from 'DA' by a simple inter. change. Diphosgene was discovered so long ago as 1847 , and mustard gas in 1822, and bromoacetone in 1863. Although it was not actually used in the War, chloroacetophenone had been discovered by Graebe in 1871, and even lewisite, although it was the result of investigations carried out specially during the War, was discovered in researches started in America in 1904 for purely scientific purposes.

\title{
A Recent Discovery in Sixteenth Century Botany
}

\section{By Dr. Agnes Arber}

$\mathrm{W}$ HEN, a few years ago, Prof. Walther Rytz of the University of Bern was reviewing the collections in the Botanical Institute, he brought to light a herbarium in nine folios, the existence of which had been forgotten for more than a century. The history of these volumes, so far as it could then be traced, was that in 1806 they had been received by a bookseller in Bern from an antiquary in Zurich who owed him four louis d'or which he was unable to pay; six years later, the Bern dealer sold the nine folios for a single louis d'or to a botanist, through whom they came into the possession of the Institute. Since the collection was obviously a remarkable one, and appeared to be of early date, Dr. Rytz examined it minutely. His researches and their results make a fascinating story, which is now set out in fully illustrated form*.

Of the nine folios, the herbarium occupies eight, while the ninth contains illustrations alone. The herbarium is far from complete; there is reason for believing that about ten more volumes may await some future happy discovery. Even in its incomplete form the collection contains 813 species drawn from a wide geographical area-Switzerland, Italy, France, Spain and Egypt. It also indicates activity of an adventurous kind, for there are specimens from Pilatus, Monte Baldo and the mountains of Savoy-peaks arousing little emotion among the alpinists of to-day, but most formidable in the eyes of the men of earlier centuries.

* Das Herharium Felix Platters. Ein Beitrag zur Geschichte der Botanik des XVI. Jahrhunderts. By Prof. Walther Rytz. (Verhandl. Naturforsch. Gesellsch. Basel, 44, pt. 1), 222 pp., 22 figures. (Basel: Naturforsch. Gesellsch., 1933.) 5 Sw. fr.

Pflanzenaquerelle des Hans Weiditz aus dem Jahre 1529: die Originale zu den Holzschnitten im Brunfels'schen Kräuterhuch. By Prof. Walther Rytz. 44 pp., 15 coloured plates. (Bern: By Prof. Walther Rytz. 60 Sw. fr.
The dried plants are well preserved and arranged, and some of them have retained their colour admirably; this point must have been regarded as of special importance, for, in some species of Campanula, the difficulty that the corollas turn brown on drying has been met by replacing them by imitations cut out of larkspur flowers! There are numerous inscriptions on the sheets, and all the information which could be gleaned from these has been brought together and analysed by Dr. Rytz, who has also made an exhaustive study of the paper used for mounting-a study which reveals no less than forty more or less different watermarks. All this research leads directly to the conclusion that the collection was formed in the second half of the sixteenth century by a botanist who was in relation with Charles de l'Écluse (1525-1609), Conrad Gesner (1516-65) and Joachim Camerarius (1534-98), from all three of whom he received specimens. After a process of delicate detective work, too complex and detailed to be summarised here, Dr. Rytz has decided that the herbarium was undoubtedly the work of Felix Platter, an eminent physician of Basle, who lived from 1536 until 1614. Fortunately, the facts of his life have been fully recorded and a fine contemporary portrait was available for reproduction in Dr. Rytz's first memoir.

From 1552 until 1557, Platter is known to have studied medicine at Montpellier, like so many botanists of his day, for example, Conrad Gesner, Jaques Dalechamps, Charles de l'Écluse, Jean Bauhin, Pierre Pena and Jean de l'Obel. In his diary of 1554, Platter speaks of collecting "viler kreuter, die ich in papier zierlich inmacht", so it is clear that he had already begun a herbarium 
soon after the middle of the sixteenth century. There is evidence that all European herbaria can be traced back to the influence of Luca Ghini, the Italian man of science, from whom William Turner, the 'father of British botany', learned to dry plants. Rondelet also, Felix Platter's teacher at Montpellier, was probably instructed in the art of herbarium-making by Ghini, and then disseminated this art among his pupils. The interchange of dried plants between savants played a very important part in the beginning of scientific systematics, and illustrations often seem to have been drawn from them. This is shown by the fact that in August 1563 Conrad Gesner wrote to Jean Bauhin: "At this time I cannot occupy the artist with dried plants : he can scarcely now paint all the fresh and green examples: I put off the dried specimens to the winter, when there will be no opportunity of getting the living".

The oldest herbaria usually consisted of dried plants alone, but the collections of Gaspard Bauhin and Felix Platter were exceptions in including figures as well as actual specimens. In the Platter herbarium there are 650 woodcuts ; most of them are from well-known herbals of the period, but there is also a rough though specially interesting set of pictures, which appear to be proofs taken from the blocks prepared by Leonhard Fuchs for a projected new edition of his herbal, which was destined to remain unpublished.

Felix Platter did not confine himself to botany : he was a renowned collector of natural and artistic treasures of all kinds, and various foreigners who visited his 'cabinet' have left records of their impressions. Among them was Michel, Seigneur do Montaigne, who was amused at the 'mignardise' of Platter's house, but took pleasure in the herbarium, when he passed through Basle on his way to Italy in 1580 - the very year in which the first edition of the "Essais" was published. A collection of dried plants was evidently a new toy to him. He writes of "un livre de simples ... an lieu que les autres font pindre les herbes selon leurs couleurs, lui a trouvé l'art de les coler toutes naturelles ... sur le papier". He notes with surprise that the pages could be turned over without the plants dropping out, and that some of these were actually more than twenty years old.

The ninth folio, which is of illustrations alone, seems to be the last survivor out of a set of similar volumes, of which no less than twenty-three have disappeared-perhaps to be redeemed by future search. The surviving volume contains 667 woodcuts mostly derived from printed herbals, and a fow copperplate etchings. There are also watercolour drawings, which are of peculiar interest, since they include a number which Dr. Rytz recognised at once as corresponding closely to the woodcuts by Hans Weiditz in the great "Herbarum Vivæ Eicones" of Otto Brunfels (1530). This book marks the beginning of an epoch in plant illustration; it has been elucidated from the botanical point of view by the authoritative work of Dr. T. A. Sprague of the Kew Herbarium (J. Linn. Soc., Bot., 48 (1928)). Critical comparison of the newly-discovered paintings with the woodcuts leaves no doubt that these drawings, which are water-colours with a bistre outline, are the actual originals from which the blocks in the herbal were made. In the second of Dr. Rytz's two memoirs, there are admirable colour reproductions of thirty of these paintings ; botanists thus have the opportunity of themselves comparing them with the outs in Brunfels' herbal.

It may seem surprising that Weiditz should have taken the trouble to colour the drawings, when they were to be reproduced as woodcuts, but Dr. Rytz has shown convincingly that the colour was chiefly intended to assist the man who would copy the outline on to the block, and also the woodcutter who would complete the process. The colouring is not used for its own sake, as in Albrecht Dürer's plant studies, but is employed with the definite object of heightening the comprehension of the form, and thus giving confidence to the copyist and enabling him to achieve a free and virile outline.

Weiditz worked on both sides of the papera luckless economy which led Platter, who was a man of method, to mangle the drawings cruelly in cutting out as many as possible in order to stick them into the appropriate places in his collection. On the backs of some of them, which have now been unstuck for examination, fragmentary inscriptions in the handwriting of Weiditz have been detected. They include directions to the craftsmen, and, on one fortunate page, the date "1529" has escaped Platter's scissors.

In a brief summary such as this, it is impossible to do justice to the indefatigable scholarship with which Prof. Rytz has extracted and evaluated every particle of ore from the rich vein which he has struck. His study has many interesting aspects which cannot be indicated here, but a parallel which he suggests may be cited in conclusion. He shows that there is a certain correspondence between the history of botany and the history of human anatomy. He compares the importance to botany of Hans Weiditz's paintings, with the importance to anatomy of the drawings of Leonardo da Vinci and Vesalius. One of the results of reading Dr. Rytz's work is, indeed, an enhanced sense of the significance of the role of artists in the biological renaissance of the sixteenth century. 